\title{
Outlining Gay's Right to Health in Jember, Indonesia: Challenges and Opportunities
}

\author{
Dewi Rokhmah \\ University of Jember, Indonesia \\ dewirokhmah@unej.ac.id
}

Khoiron

University of Jember, Indonesia

khoiron@unej.ac.id

\section{Ristya Widi Endah Yani}

University of Jember, Indonesia

ristya_widi@unej.ac.id

\begin{abstract}
Increased HIV prevalence in gay populations is a warning that needs to get government attention. AIDS prevention programs in gay populations have been implementing various methods to change high-risk behavior. However, HIV prevalence in gay populations continues to rise. The Indonesian Constitution affirms human rights, including the right to life, the right against discrimination, and other fundamental rights protected by the state. The research results showed that the fulfillment of the right to health in gay is not going well or less effective. It was evidenced by the percentage of gay that reaches out to health services was still limited. Gays were reluctant to access health services because of the lack of confidentiality and privacy of the services of health workers, the general public, and the limited facilities. Besides, stigma and discrimination are still often received both from health workers and families and communities. They worried other gays would know the result of the test of VCT. There is a need for standardization of services at all subdistrict health centers and hospitals providing VCT services for gay in Jember.
\end{abstract}

KEYWORDS: Constitutional Rights, Human Rights, the Right to Health.

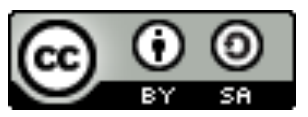

Copyright $\odot 2020$ by Author(s)

This work is licensed under a Creative Commons Attribution-ShareAlike 4.0 International License. All writings published in this journal are personal views of the authors and do not represent the views of this journal and the author's affiliated institutions.

\section{HOW TO CITE:}

Rokhmah, Dewi, et al. "Outlining Gay's Right to Health in Jember, Indonesia: Challenges and Opportunities” (2020) 7:2 Lentera Hukum 137-152

Submitted: April 08, 2020 Revised: July 23, 2020 Accepted: July 24, 2020 


\section{INTRODUCTION}

The gay phenomenon is a classic social problem because it had existed over centuries, and even before humans recognized modern civilization. ${ }^{1}$ Therefore gay life becomes inseparable in human civilization. We all had known that the majority of society dislike homosexuality. It is behavior disruptive to the times. One must worry because homosexuality does not only affect generation but also affect public health in general. ${ }^{2}$ Amid a firm community rejection, with the emergence of homophobia, gays' existence has never been disappeared in people's lives. Especially in traditional societies, gays are considered sick, wrong, or sin. ${ }^{3}$ It is different again in the life of postmodern society that changes the way people view sexuality. In the space of postmodernism, sex is no longer a private matter, but a matter of a public nature. After entering public space, sex becomes a potential commodity to be traded. Sex is no longer a scarce item that has a sacred value but has become an activity sold off indefinitely. ${ }^{4}$ As well as the increasingly open gay sexuality of sex and become a serious problem related to the high rate of transmission of Sexual Transmission Infections (STIs) and Human Immunodeficiency Virus (HIV)/Acquired Immune Deficiency Syndrome (AIDS) in gay communities in the last few years.

Gay becomes a popular terminology in the context of HIV and AIDS. This terminology is used because it describes behavior that puts them at risk of being infected. ${ }^{5}$ As the most secret society, gay, especially among adolescents, is complicated to reach by HIV/AIDS prevention and prevention programs. On the other hand, their behavior is hazardous to the spread of HIV/AIDS, such as changing sexual partners without using condoms and lubricants and perform oral and anal sex. ${ }^{6}$ In fact, the more covered an gay in socializing with others, there is a tendency to increase the risk for those affected by sexually transmitted infections (STIs) and HIV/AIDS .?

A report from Indonesia's Ministry of Health states that the cumulative number of HIV/AIDS cases from the first case finding in April 1987 to June 2014 already contained 55,623 numbers. Men were 29,882 and women were 16,092, and the rest were not known for their sexual identity. ${ }^{8}$ National AIDS Commission believes that in the next decade,

1 Gunawan Saleh \& Muhammad Arif, Rekayasa Sosial Dalam Fenomena Save LGBT, (2017) 6:2 Jurnal Komunikasi Global, at 148-163.

2 Suherry, et al, Lesbian, Gay Biseksual dan Transgender (LGBT) Dalam Perpektif Masyarakat dan Agama, (2016) 4:2 Jurnal Aristo, at 91.

3 Sarlito W. Sarwono. Psikologi Lintas Budaya. (Jakarta: PT Raja Grafindo Persada, 2014).

4 Ampy Kali. Diskursus Seksualitas Michel Foucault. (Maumere: Penerbit Ledalero, 2013).

5 Argyo Demartoto. Mengerti, Memahami dan Menerima Fenomena Homoseksual. (Semarang: Universitas Diponegoro, 2010).

6 Dewi Rokhmad \& Khoiron, Youth and HIV/AIDS: Sexual Lifestyle of Youth MSM (A Man Who has Sex with a Man) and its Risk Towards HIV and AIDS Infection. (2015) 3:4 International Journal of Current Research and Academic Review.

7 Dewi Rokhmah, et al, Proses Sosialisasi MSM (Laki-Laki Suka Seks Dengan Laki-Laki) di Kalangan Remaja Dan Dampaknya Pada Kesehatan Reproduksi Remaja. (2012) 8:2 Jurnal Ilmu Kesehatan Masyarakat (IKESMA).

8 Directorate General of Disease Prevention and Environmental Health, The Ministry of Health of the Republic of Indonesia. The Report of Directorate General of Disease Prevention and Environmental Health, The 
the new transmission will be dominated by a sexual transmission that accounts for $70 \%$ of new transmission. ${ }^{9}$ In 2010, there was an estimation that $77 \%$ of male HIV cases stemmed from male-to-male sexual relations. ${ }^{10}$

Increased HIV prevalence in gay populations is a warning that needs to get government attention. AIDS prevention programs of gay populations have been implementing various methods to change high-risk behavior. However, HIV prevalence in gay populations continues to rise. The results of the Integrated Biology and Behavior Survey (STBP) in 2011 and 2013 indicate an increase in HIV prevalence in gay populations. In Jakarta, Bandung, and Surabaya in 2007 and 201l, there was an increase in prevalence percentage from $8.1 \%, 2.0 \%$, and $5.1 \%$ to $17.2 \%, 10.4 \%$, and $9.8 \%$. In the 2009-2013 STBP results, in other big cities, Yogyakarta and Tangerang have increased the percentage of HIV prevalence among gay from $7.9 \%$ and $9.5 \%$ to $20.3 \%$ and $18.8 \%$, respectively. Only Makasar City declined from 3.0\% in 2009 to $1.6 \%$ in 2013. ${ }^{\text {Il }}$ The Ministry of Health of the Republic of Indonesia and Family Health Indonesia (FHI) in 2012 conducted a study of 275 gay giving an overview of how the sexual network among risk groups Very complicated. Male sex worker whose customers are gay, it also bought sex from female sex workers (FSW). ${ }^{12}$

Meanwhile, in East Java, the total of HIV disease, according to the report published by the ministry in 2019, was 52,774 cases with the reported data of 17,929 cases. Surabaya, as the provincial capital, tops the list of HIV/AIDS cases compared to other cities in East Java. HIV/AIDS cases were estimated to reach 19,503 numbers with the reported data of 7,412 cases. $^{13}$

Unlike in East Java, several districts and cities fall into the category of concentrated areas for the discovery of HIV and AIDS cases. Jember Regency is included in East Java's regency with the discovery of high HIV and AIDS cases. Cumulatively, the number of people with HIV/AIDS in Jember District according to a report from the Jember District Health Office since the first case was found in 2004 to 2015 always increased in each year. Until June 2016, the number of people living with HIV/AIDS has reached 2,600.14 Based on the risk factor, the highest case came from heterosexual behavior as much as 2,251

Ministry of Health of the Republic of Indonesia. (Jakarta: Directorate General of Disease Prevention and Environmental Health, The Ministry of Health of the Republic of Indonesia, 2012).

9 National AIDS Commission. National AIDS Commission 2007-2010 HIV and AIDS Response Strategies. (National AIDS Commission, 2007).

10 Center for Disease Control and Prevention USA. (2012).

11 The Ministry of Health of the Republic of Indonesia. STBP (Surveilens Terpadu Biologis dan Perilaku). (Jakarta: Direktorat Jenderal Pengendalian Penyakit dan Penyehatan Lingkungan, 2013).

12 Ignatius Praptorahardjo, et al. Kebijakan HIV \& AIDS dalam Sistem Kesehatan di Indonesia: Ringkasan Kajian Dokumen. (Yogyakarta: Pusat Kebijakan dan Manajemen Kesehatan Fakultas Kedokteran Universitas Gadjah Mada dan Departement of Foreign affairs and Trade, Austalian Government, 2014).

13 Directorate General of Disease Prevention and Environmental Health, supra note 8.

14 Jember District Health Office. Jember District Health Profile: Jember. (Jember: Jember District Health Department, 2016). 
cases $(86.8 \%)$, then gay as many as 190 cases $(7.31 \%)$ and mother-to-child transmission (perinatal) of 74 cases $(2.85 \%) .{ }^{15}$

The description of the life of gay in Jember District is derived from the description by Gapura Community as a gay community built by LSM Laskar Jember, which is an NGO working on HIV and AIDS prevention programs together with KPAD and Jember District Health Office. Based on data from Gapura Community, currently, in the Jember district, there are approximately 950 gay. If the number is compared with the total population in Jember Regency, then the current gay in Jember Regency is $0.03 \%$. Real numbers can not be ascertained because most gay is still closed (hidden). ${ }^{16}$ Unlike in other countries, Whitam and Malty (1985) in Siahaan (2009) say that gayity exists in all cultures and all historical events in relatively small numbers $(4-5 \%$ of the male population)..$^{17}$

Preparing health services for them is essential to control HIV/AIDS. As an illustration of data from the Jember District Health Office (2016), the prevalence of gay who performs VCT diagnosed HIV/AIDS from 2011-2015 experienced a significant increase. In 2011, 38 gays checked on VCT, and six were positive. Then, in the following year shows the following figures: 19 gays checked for VCT, and there were nine positives (2012), 53 gays checking for VCT there are 15 positives (2013), 205 gays checked to VCT there were 31 positives (2014), and 405 gays checked for VCT there were 48 positives (2015).

The conditions mentioned above are worsened by the complexity of sexual networks of gays, where male sex workers for gays also engage in sexual transactions with Women Sex Workers. On the other hand, the high level of stigma and discrimination by our society in groups of gay makes it difficult for them to access health and quality health services related to STIs, including HIV and AIDS. The HIV/AIDS community now has considerable challenges in clarifying and addressing the needs of gay in sub-Saharan Africa; homosexuality is illegal in most countries (including Indonesia), and political and social hostility is endemic. An effective response to HIV/AIDS requires improved strategic information about all risk groups, including gay. The belated response to gay with HIV infection needs rapid and sustained national and international commitment to the development of appropriate interventions and action to reduce structural and social barriers to make these accessible. ${ }^{18}$

In order for gays to be accepted by their communities, one of them is forming an organization that is expected to be an effective bridge to communicate with "normal" people in general. Through their organization, they expected to have the power to

15 Jember District Health Office. Laporan Program Penanggulangan HIV dan AIDS di Kabupaten Jember Tahun 2016. (Jember: Bidang P2PL Dinas Kesehatan Kabupaten Jember, 2016).

16 Gapura Community. Laporan Kinerja Gapura Community Tahun 2016. (Gapura Community, 2016).

17 Jokie M.S. Siahaan. Perilaku Menyimpang: Pendekatan Sosiologi. (Jakarta: PT. Indeks, 2009).

18 Adrian D. Smith, et al, Men Who have Sex with Men and HIV/AIDS in Sub-Saharan Africa. (2009) 374:9687 The Lancet. 
demand their rights that have been ignored by the community and government. ${ }^{19}$ However, in Indonesia, gay groups are among the most vulnerable group in getting discrimination. Many regulations and laws still do not acknowledge the existence of human rights for gay individuals and groups. The homophobic views still often dominate the government and society, and these views discredit gay. ${ }^{20}$ Therefore, the Indonesian constitution clearly and decisively has been regulated in chapter 28 of the Constitution of 1945 that regulates human rights, including the right to life until the right not to get discrimination and other fundamental rights that must be protected by the state. In the case of access to quality health care was the right of every citizen, not least the gay group. Article $28 \mathrm{H}$ of the 1945 Constitution guarantees every person has the right to live physically and mentally prosperous, including the right to life, and to have a healthy living environment and the right to receive health services. These rights are also outlined in Act No. 39/1999 on Human Rights. Article 9 paragraph (3) of this Act takes a considerable guarantee for every person to have a good and healthy environment. The criminalization of consensual sexual practices among adults increases the frequency of human rights violations contributing to the incidence of HIV infections.

Furthermore, marginalization and disempowerment of gay limits their livelihood opportunities increase the prevalence of sex work and drug use and limits financial access to HIV services. ${ }^{21}$ Accordingly, the gay community is always identified with risk behavior. Evidenced by cases of HIV/AIDS, among them are increasing every year. The community's rejection exacerbates this condition to them. Therefore, their access to health services experiences many obstacles. This paper aims to analyze the challenges and opportunities in fulfilling the rights of the community of gay towards health services.

The data collection was made in two ways, namely primary data and secondary data. The primary data was collected from an in-depth interview. The step to do in-depth interviews, first researchers were doing in the form of adaptation of researchers in order to be well received by the subjects. Researchers should create a non-formal or kinship situation. The principle is the analysis focused on understanding the participant's world and then focusing full time on the transcripts (and listening to recorded conversations) to identify the main themes. The analysis began with a single case and continued in subsequent stages. ${ }^{22}$

This paper consists of two parts of discussion. The first part will highlight the access of gay to the health services. The second part will discuss the challenges of health services accessible for gay. This paper concludes that the right to health provided for gay is not per the planned objective because the percentage of gay that reaches out to health

19 Akh. Syamsul Munir \& Nur Shofa Ulfiyati. Hak Asasi Manusia dalam Islam dan Eksistensi LGBT di Indonesia. Prosiding Seminar Nasional dan Temu Ilmiah Jaringan Peneliti.

20 Yulianti Muthmainnah, LGBT Human Rights in Indonesia Policies, (2016) 4:1 Indonesian Feminist Journal, at 21 .

21 Andrew Scheibe, et al, Money, Power, and HIV: Economic Influences and HIV Among Men Who have Sex with Men in Sub-Saharan Africa. (2014) 18:3 Africa Journal Reproductive Health. at 84-92.

22 Darren Langdridge. Phenomenological Psychology; Theory, Research, and Method. (London: Pearson Education, 2007). 
services was still limited. Many gays are reluctant to access health services because of the lack of confidentiality and privacy of the services of health workers and the general public and the limited facilities. Also, stigma and discrimination are still often received both from health workers and families and communities.

\section{GAY'S ACCESSIBILITY OF HEALTH SERVICES}

During 2015-2016, there was an increase in the number of gay in the Jember district. In June 2015, there were 179 people; in July 2015, there were 238 people, and it continued to increase until November 2015 by 346. However, in December 2015, it decreased to 299, and in January 2016, more decreased to 182 people. The data showed that the amount of gay tends to increase every month because of the change of value in the society where the gay community widely encountered. As a result, gay, which initially covered its identity as gay (hidden), then disclosed the identity in society as gay. Many gays discussed how their development of gay identity was a process that some of them were still in the midst of, while others were more firmly established in their gay identity. ${ }^{23}$ This supported by the research occurred in Chengdu (China) gay man may divide their friends into two circles, those who are gay and those who are not. ${ }^{24}$ There were three phases that gay would be through awareness phases, denial phases, and acceptance phases. When gays accept their condition, gays will reveal their true identity. ${ }^{25}$ Gay people in Indonesia have begun to show their identity in the sociality. However, the existence of gay in society makes it difficult for gay to make a social adjustment. The previous research proved that if gay people tried to come out, the social environment did not accept their existence. The environmental stressor that could be accepted by gay was bullying. ${ }^{26}$

Based on marital status, data obtained from Jember District Health Office (2016) indicates that the number of gays based on their Marriage Status is from 2.120 gays, most of them unmarried at $1.783(84,1 \%)$. At the same time, the status of married is 191 (9\%), and the status of divorce is $35(1,65 \%)$. Under Law Number 16/2019 concerning the amendment to Law Number 1/1974 concerning Marriage Article 7 in which marriage is only permitted if men and women have reached the age of 19 (nineteen) year. ${ }^{27}$ It means that marriage will be officially recognized by the state when committed between men and women. Thus, it makes sense if gay marriage as a large unmarried and even some who have divorced. If we focused on the total status of married is $191(9 \%)$, based on the previous study, many gays are interested in having and rearing children. It is undeniable that gays can marry women for having a child. Given the importance to individuals of

23 Kevin John Zimmerman, Maintaining Commitment in Long-Lasting Mixedorientation Relationships: Gay Men Married to Straight Women. (2013) Lowa State University Digital Repository, at 79.

24 Yuji Feng, et al, Evolution of MSM Community and Experienced in Stigma Among MSM in Chengdu, China. (2011) NIH Public Access.

25 Anisa Diniati Konstruksi Sosial Melalui Komunikasi Intrapribadi Mahasiswa Gay di Kota Bandung. (2018) 6:2 Jurnal Kajian Komunikasi, at 147-159.

26 Gallo Ajeng Yusinta Dewi \& Endang Sri Indrawati, Pengalaman Menjadi Gay (Studi Fenomonologi pada Pria Homoseksual Menuju Coming Out). (2017) 7:3 Jurnal Empati, at 116-126.

27 Law Number 16/2019 Concerning the Amendment to Law Number 1/1974 Concerning Marriage. 
having children, there is no sound basis for denying gay the same rights to reproduce those other individuals have. ${ }^{28}$ Another research showed that the reason gays get married because they believe that otherwise, no one will be there to take care of them in their old age, and another reason was that their parents forced them to marry. ${ }^{29}$ Besides, the reason for getting married that gays expected to be normal. ${ }^{30}$ There also a research showed that their wives knew that they are a gay, and it made their wives depression. ${ }^{31}$ Previous studies about the reasons why gay married a woman. The most common reason given for marriage is love. Another reason because they believed that doing so would lessen or eliminate their same-sex attractions. ${ }^{32}$

Besides, from the results of the study obtained data that from 2.120 gay from the level of education mostly only educated at the level of Senior High School that is equal to 1,376 gays (64.9\%), then graduated from Junior High School is 397 (18.72\%) and for elementary school graduates of 105 gays (4.95\%). For college-educated level only 135 $(6.37 \%)$. It means that most of them have a high level of education. The level of education that visible on the surface cannot reflect gay behavior. ${ }^{33}$ From these data, it can also be concluded that compared with other high-risk groups such as transgender, the female sex worker (FSW), or the injecting drug user (IDU), the community has a secondary education level. In comparison, other high-risk groups like FSW are mostly lowly educated. The average of the youth. This condition Is similar with the result of the research conducted by Rokhmah and Oedojo (2015) which the research about Sexual lifestyle of youth gay and its risk towards HIV and AIDS infection showed that gay in Jember aged 17-23 years have a regular sexual partner whose single status at 19-27 years, most of them were from high education. In general, they have parents from low education and work as farmers, businessmen, and government employees. Low education of parents could cause a low understanding of sex education. So the child does not get about sex education. ${ }^{34}$ Besides having parents from low education that can affect gay behavior, another research showed that association factor, culture, and motivation could affect sexual deviation on gay. ${ }^{35}$

There is a high risk of gay sexual behavior on HIV/AIDS, such as having oral and anal sex with multiple partners without using condoms and lubricants (Rokhmah et al.,

${ }^{28}$ The American Society for Reproductive Medicine, Access to Fertility Treatment by Gays, Lesbians, and Unmarried Person: a Committee Opinion, (2013) 100:6 Fertility and Sterility.

29 Charapani, et al, India "MSM Situation Paper" Series Technical Brief 2, (2011) UKaid from the Department for International Development, at 6-7.

30 Ibid

31 Irma Rosalinda Lubis \& Ananda Rasullia, Penerimaan Diri pada Istri yang Memiliki Suami Homoseksual, (2014) 3:2 Jurnal Penelitian dan Pengukuran Psikologi, at 83.

32 Ibid

33 Hardisman, et al, Model Determinan Perilaku "Lelaki Seks Lelaki" di Kota Padang Sumatera Barat, (2018) 7:3 Jurnal Kesehatan Andalas, at 309.

34 Dewi Wahyuni, Peran Orang Tua dalam Pendidikan Seks Bagi Anak Untuk Mengantisipasi LGBT, (2018) 14:25 Quantum, at 26.

35 Maria M. Pontoh, et al, Hubungan Pola Asuh Orang Tua dengan Tingkat Homoseksual Pada Komunitas Gay X di Manado, (2015) 3:3 Jurnale-Biomedik (eBm), at 902. 
2016). Based on the study results, it finds that from 2,120 gays, there were 1,809 (85.3\%) who did not fill the health care setting. According to the Laskar NGO, the accompanying field officers explained that there are still many gay, especially from middle to upper class who have not to access health services provided by the government. Besides, the comfort factor and concerns that others will know their identity as gay, it is also because they feel more privacy when accessing private doctor services. The use of services for gay provided by the government includes the examination of STIs, VCTs available at Puskesmas and Hospitals.

In contrast, CST Service is available in Hospitals only. The Universal Declaration of Human Rights (UDHR) explained that all people have the right to associate freely and peacefully. This statement is supported by The International Covenant on Civil and Political Rights that the meaning of "associate freely" is there must be no restrictions on the rights to public security, public order also the rights to health protection. It means that gay also has a right to get and access health protection. ${ }^{36}$

This paper concluded that from 2.120 gay-only 291 (13.7\%) gay using service at the Center of Public Health. At the same time, only 20 (0.94\%) people use the service in the hospital. The search results with gay escort officers from Laskar NGOs said that the cause is that they are reluctant to the hospital because the hospital still has to queue long and pay the registration fee at the Patient registration counter. Meanwhile, if they use the Puskesmas service, they feel more comfortable because it is not subject to the registration fee and service fee, and the officers are very friendly to gay. In China, HIV transmission among men who have sex with men (gay) is surging, yet many HIV-positive gays do not use HIV care services. ${ }^{37}$ Previous research that occurred in Guangxi Zhuang Autonomous Region (one of the districts in China) showed that many HIV-positive gays did not use HIV care services because it was applied to name-based testing. They definitely would not seek testing if this policy were implemented in their province. Another reason is relationship type and partner characteristics. Some participants said they did not seek testing because they were in a long-term relationship or because they and their partner trusted each other. ${ }^{38}$

\section{GAY'S CHALLENGES FOR HEALTH SERVICES}

The results of interviews with the Jember District Health Office show that in the Field of Control and Prevention of Infectious Diseases revealed that access to gay services had not shown maximum results. During this time, the Health Office of Jember Regency has established cooperation with LASKAR NGO in Jember, which concern at HIV/AIDS

36 Olivia J.S. Taebenu, The Protection of LGBT (Lesbian, Gay, Bisexual, Transgender) Rights According to Human Rights, (2014) 2:8 Lex Ex Societatis., at 104.

37 Yu Liu, et al, Barriers and Facilitators of Linkage to and Engagement in HIV Care Among HIV-Positive Men Who Have Sex with Men in China: A Qualitative Study, (2016) 30:2 Journal of AIDS Patient Care and Sexual Transmitted Disease, at 70-77.

38 Chongyi Wei, et al, Accessing HIV Testing and Treatment among Men Who Have Sex With Men in China: A Qualitative Study, (2014) 26:3 National Institute of Health. 
program in reaching gay. There was a specific program issued by the Ministry of Health of the Republic of Indonesia named SUFA (Strategic Use of ARV) Program launched in the middle of 2013, which aimed to increase coverage of HIV testing, increase coverage of ART, and improve retention of ART. SUFA was implemented in 13 districts/cities and expanded gradually in 2014 in 75 districts/cities. Jember District got a mandate to implement a SUFA program, especially for the community of gay executed by the Health Office of Jember District in cooperation with Laskar NGO.

In practice, SUFA emphasizes TOP, is an extension of Discover, Treat, and Preserve. Finding Positives means offering HIV testing to everyone who has risky behavior, offering routine HIV testing to pregnant women, TB patients, hepatitis, STIs, People Leaving with HIV/AIDS (PLHA) couples. For crucial populations whose HIV status is still negative, a retest is performed at least every six months. Next is found Obati, which provides treatment for those who already meet the criteria of starting antiretroviral treatment (ARV) early if the CD4 count is 350 or starting antiretroviral treatment regardless of their CD4 cell count in people living with AIDS 3 or 4, Pregnant, TB patients, Hepatitis patients, and HIV positive vital populations. Antiretroviral drugs can be a combination of several drugs or fixed-dose combinations (KDT/FDC). The earlier the HIV patient is given antiretroviral, the amount of virus in his blood will decrease, and the risk of transmission to others is also reduced, so the quality of his life improves. The latter is the Treated Preserve. That is, ensuring patients are dutifully taking the lifelong medication by assisting primarily at the start of treatment and providing appropriate support from the family, community, peer support groups, and healthcare services.

From the concept of the SUFA program, especially to gay, it is expected that more gay will go to health service to know their HIV/AIDS status and get treatment immediately. However, the field obtained the fact that from the total number of total Gay that has been established LSM Laskar for 2,120, only 13.7\% who accessed services in The Centre of Public Health included VCT services and STI examination. In comparison, gay accessing hospital services (sti, vct and cst services) was only $0.94 \%$. This proves that gay in Kabupaten Jember did not access health services optimally. Otherwise, to get a good health service is the right of every citizen without exception as mandated in the law and government regulations.

According to the in-depth interview with health workers from the Health Office and the Laskar NGO counterparts, there are several reasons why gays are reluctant to access the government's health services in both the Centre of Public Health and the hospitals. They worried about knowing the result of the VCT test or STD test. They were not ready to receive the result of the test because they did not know that STD and HIV/AIDS could be prevented and reined. It means that the knowledge of gay HIV/AIDS is still low. Though the knowledge about HIV/AIDS is high, it cannot guarantee that gay will be free of HIV/AIDS. The research supports this in Buenos Aires that correct knowledge is not enough to cause behavior changes. It is a necessary precursor to 
employing effective HIV risk reduction behaviors. ${ }^{39}$ Based on the data reported by the Health Office of Jember District showed the number of gay in Jember District as are those who have come out or opened their self-identities as gay to escort officers. While most of the gay in the community still cover their status and live in hidden (hidden). Some studies supported this result in the reason why gay hides their identity. One of the research that occurred in Beijing China that the reasons gay hide their status/identity is avoiding the stigma and discrimination that accepted by people around. This statement also supported by the research, keeping the family value. Also, there was a government regulation to keep gay identity secretly. ${ }^{40}$ As a result, those who have received comprehensive information about HIV/AIDS are still low. Proven with concerns if their status is positive HIV/AIDS, then their worry cannot be cured and will die. This condition is the same with the research about the barrier in HIV care among HIV positive gay in Cina that the significant barriers to linkage to HIV care documented in this study included: (1) perceived discrimination from health care workers; (2) lack of guidance and follow-up; (3) clinic time or location inconvenience; (4) privacy disclosure concerns; (5) psychological burden of committing to HIV care; and (6) concerns about treatment. ${ }^{41}$ These results concur with earlier studies that there was a strong association between ever experiencing discrimination, including denial of healthcare services and blackmail based on sexuality, and fear of health care services. ${ }^{42}$

Besides, gay still needs much money to access health services; most of them coming out is still in low economic condition. People around can no accept gay sexual deviation. Many gays joblessness and financial crisis. ${ }^{43}$ Sometimes not infrequently many gays, which then becomes stressful. ${ }^{44}$ Most of the gay still exist in a hidden community. This is revealed by the gay companion from Laskar NGOs, who revealed that most gay people who have known HIV/AIDS status coming from lower-middle classes. So they hope that the health services obtained are free of charge. This can be obtained at the Centre of Public Health. While at the hospital still need registration fee at the counter. This condition is like the result of research indicating that gay in Jember more access service at the Centre of Public Health than in Hospital.

Stigma and discrimination still happen in health providers (the new one) and from their community and the family and society. Stigma and discrimination from health workers have been identified as one of the majority of the significant reason for gay do

39 Maria A. Pando, et al, HIV Knowledge and Beliefs among Men Who Have Sex With Men (MSM) in Buenos Aires, Argentina, (2013) 17:4 AIDS Behav, at 5.

40 Toby Miles-Johnson \& Yurong Wang, "Hidden Identities": Perception of Sexual Identity in Beijing, (2018) 69:2 The British Journal of Sociology.

41 Ibid.

42 Heather Fay, Stigma, Health Care Access, and HIV Knowledge Among Men Who Have Sex With Men in Malawi, Namibia, and Botswana, (2011) 15:6 AIDS Behav, at 1093.

43 LaRon E. Nelson, et al, Economic, Legal, and Social Hardship Associated with HIV Risk among Black Men Who Have Sex With Men in Six US Citie, (2016) 93:1 Journal of Urban Health: Bulletin of the New York Academy of Medicine.

44 Jennifer A. Pellowsky, et al, A Pandemic of the Poor: Social Disadvantage and the U.S. HIV Epidemic, (2014) 68:4 National Institute of Health. 
not use health services. ${ }^{45}$ This is the same with the research in Swaziland in Sub Saharan Africa that stigma was prevalent, including $61.7 \%$ reporting fear of seeking healthcare, $44.1 \%$, any enacted stigma, $73.9 \%$, any perceived social stigma (such as from family members and friends). Ever disclosing sexual practices with other men to healthcare providers was low $25.6 \% .{ }^{46}$ Our society still rejects the gay and the other key populations that have risky behavior like IDU, FSW, and transgender. Indonesia is a country that does not legalize the gay community. So, people strongly reject the existence of this community. Likewise, Jember is known as a santrit ${ }^{47}$ city because there are many Islamic boarding schools in this city. Therefore Jember is better known as a religious city. Islamic law is a legal system that, if properly implemented, will create a benefit. Therefore Islam forbids gay behavior. Because it can cause various diseases, one of which is HIV/AIDS. ${ }^{48}$ As a result, in-depth interviews with some gay revealed that sit-ins and discrimination against gay were frequent, not only from the community and health workers, even from gay communities themselves often found stigma and discrimination, especially in gay who were HIV/AIDS positive. Significant barriers to testing included gay and HIV related stigma and discrimination, relationship type and partner characteristics, low perception of risk or threat, HIV is incurable or equals death, concerns of confidentiality, unaware that testing is offered for free, and name-based testing. ${ }^{49}$

According to the causes mentioned above, the government has a responsibility to provide solutions for gay to have access to adequate health services. The programs not only complete the facility of health service but also prepare the health officer (human resources) to give service to the gay friendly. The primary solution to overcome this particular barrier to HIV testing in education. Physicians should be familiar with the CDC's revised recommendations for HIV Testing of Adults, Adolescents, and Pregnant Women in Healthcare Settings and the rationale behind them. ${ }^{50}$ However, gay are citizens with equal rights with other citizens in obtaining access to appropriate health services, as mentioned in the Article $28 \mathrm{H}$ of the 1945 Constitution guarantees that every person has the right to live physically and mentally prosperous, to live and to have a healthy living environment and the right to receive health services. It is also guaranteed by Law No. 39/1999 on Basic Human Rights. Article 9 paragraph (3) of Law 39/1999 guarantees every person the right to a good and healthy environment. The training combined self-directed and facilitated group learning, increased health worker knowledge, and reduced homophobic attitudes up to three months after training. Scaling up such interventions offers a straightforward response to the immediate need to

45 Ibid.

46 Kathryn Risher, et al, Sexual Stigma and Discrimination as Barriers to Seeking Appropriate Healthcare Among Men Who Have Sex With Men in Swaziland, (2013) 16:3 Suppl 2 Journal of the International AIDS Society.

47 Santri is often referred to the term to address the student at Islamic boarding educational institutions.

48 Ibid.

49 Ibid.

50 Stacey A. Rizza, et al, HIV Screening in The Health Care Setting: Status, Barriers, and Potential Solution. (2012) 87:9 Symposium On Antimicrobial Therapy. 
support healthcare workers in offering accessible and informed services to address the most sexual health needs among gay in Kenya. ${ }^{51}$ Previous research suggested that online gay sensitization training combined with group discussions can be a promising approach to improving health providers' awareness, attitudes, and beliefs about the health needs of gay patients. ${ }^{52}$ Besides that healthcare workers recommended clinic staff sensitivity training, use of trained gay peer navigators, and stigma reduction in the community as interventions that might improve adherence and health outcomes for gay. Despite noting gay-specific barriers, healthcare workers recommended strategies for improving HIV care for gay in rights-constrained settings that merit future research attention. ${ }^{53}$ Another study suggested some innovative strategies to improve HIV care utilization among gay. The suggestion more likely depends on close collaboration between the government, community-based organizations, HIV care facilities and staff, and gay to create a more socially and culturally tolerant environment and a robust and comprehensive HIV care system. ${ }^{54}$

\section{CONCLUSION}

The fulfillment of the right to health in gay is not per the planned objective. This was evidenced by the percentage of gay that reaches out to health services was still limited. They were reluctant to access health services because of the lack of confidentiality and privacy of the services of health workers and the general public and the limited facilities. Also, stigma and discrimination are still often received both from health workers and families and communities. There must be a government regulation to increase the standardization of services at all public health centers and hospitals providing VCT, STI, CST services for gay in Jember District. It should be added Mobile VCT which is facilitated by NGOs and the Centre of Public Health to the hot spot of gay. To highlight stigma and discrimination, socialization of HIV/AIDS and prevention of stigma and discrimination to the key gay population is needed to emphasize stigma and discrimination, the socialization of HIV/AIDS, and the prevention of stigma and discrimination using interactive media like film and public health advertisement, both to the society and gay community.

51 Elise M. van der Elst, et al, Men Who have Sex with Men Sensitivity Training Reduces Homoprejudice and Increases Knowledge among Kenyan Healthcare Providers in Coastal Kenya. (2013) 16:4 Suppl 3 Journal of The International AIDS Society.

52 Elise M. van der Elst, et al, Experiences of Kenyan Healthcare Workers Providing Services to Men Who have Sex with Men: Qualitative Findings from a Sensitivity Training Program, (2013) 16:4 Suppl 3 Journal of The International AIDS Society.

53 Murugi Micheni, et al, Health Provider Views on Improving Antiretroviral Therapy Adherence Among Men Who Have Sex with Men in Coastal Kenya, (2017) 31:3 AIDS PATIENTS CARE and STDs, at 115-119.

54 Ibid. 


\section{ACKNOWLEDGMENTS}

We are very grateful to the Health Office of Jember Regency, Laskar NGO, which concerns HIV and AIDS Prevention in Jember Regency, East Java, Indonesia, and for their assistance in recruiting the participant's data. This research was supported by the BPD Dirjen DIKTI, The Ministry of Research, Technology, and Higher Education of Republic Indonesia. We also acknowledge gay in Jember Regency, who had volunteered as a subject or informant in this study.

\section{COMPETING INTERESTS}

The authors declare that they have no competing interests.

\section{REFERENCES}

Adrian D. Smith, et al. Men Who have Sex with Men and HIV/AIDS in Sub-Saharan Africa. (2009) 374:9687 The Lancet.

Akh. Syamsul Munir \& Nur Shofya Ulfiyati. Hak Asasi Manusia dalam Islam dan Eksistensi LGBT di Indonesia. Prosiding Seminar Nasional dan Temu Ilmiah Jaringan Peneliti.

American Society for Reproductive Medicine. Access to Fertility Treatment by Gays, Lesbians, and Unmarried Person: a Committee Opinion. (2013) 100:6 Fertility and Sterility.

Ampy Kali. Diskursus Seksualitas Michel Foucault. (Maumere: Penerbit Ledalero, 2013).

Andrew Scheibe, et al. Money, power, and HIV: economic influences and HIV among men who have sex with men in sub-Saharan Africa. (2014) 18:3 Africa Journal Reproductive Health.

Anisa Diniati. Konstruksi Sosial Melalui Komunikasi Intrapribadi Mahasiswa Gay di Kota Bandung. (2018) 6:2 Jurnal Kajian Komunikasi.

Argyo Demartoto. Mengerti, Memahami dan Menerima Fenomena Homoseksual. Artikel Seksualitas (Semarang: Universitas Diponegoro, 2010).

Center for Disease Control and Prevention USA. (2012).

Charapani, et al. India "MSM Situation Paper" Series Technical Brief 2. (2011) UKaid from the Department for International Development.

Chongyi Wei, at al. Accessing HIV Testing and Treatment among Men Who Have Sex With Men in China: A Qualitative Study. (2014) 26:3 National Institute of Health.

Darren Langdridge. Phenomenological Psychology; Theory, Research, and Method. (London: Pearson Education, 2007).

Dewi Rokhmah, et al. Proses Sosialisasi MSM (Laki-LakiSuka Seks dengan Laki-Laki) di Kalangan Remaja dan Dampaknya pada Kesehatan Reproduksi Remaja. (2012) 8:2 Jurnal Ilmu Keschatan Masyarakat (IKESMA). 
Dewi Rokhmah \& Khoiron. Youth and HIV/AIDS: Sexual Lifestyle of Youth MSM (A Man Who has Sex with a Man) and its Risk Towards HIV and AIDS Infection. (2015) 3:4 International Journal of Current Research and Academic Review.

Dewi Wahyuni. Peran Orang Tua daam Pendidikan Seks Bagi Anak Untuk Mengantisipasi LGBT. (2018) 14:25 Quantum.

Directorate General of Disease Prevention and Environmental Health, The Ministry of Health of the Republic of Indonesia. The Report of Directorate General of Disease Prevention and Environmental Health, The Ministry of Health of the Republic of Indonesia. (Jakarta: Directorate General of Disease Prevention and Environmental Health, The Ministry of Health of the Republic of Indonesia, 2012).

Elise M. van der Elst, et al. Experiences of Kenyan Healthcare Workers Providing Services to Men Who have Sex with Men: Qualitative Findings from a Sensitivity Training Program. (2013) 16:4 Suppl 3 Journal of The International AIDS Society.

Elise M. van der Elst, et al. Men Who have Sex with Men Sensitivity Training Reduces Homoprejudice and Increases Knowledge Among Kenyan Healthcare Providers in Coastal Kenya. (2013) 16:4 Suppl 3 Journal of The International AIDS Society.

Gallo Ajeng Yusinta Dewi \& Endang Sri Indrawati. Pengalaman Menjadi Gay (Studi Fenomonologi Pada Pria Homoseksual Menuju Coming Out. (2017) 7:3 Jurnal Empati.

Gunawan Saleh \& Muhammad Arif. Rekayasa Sosial Dalam Fenomena Save LGBT. (2017) 6:2 Jurnal Komunikasi Global.

Hardisman, et al. Model Determinan Perilaku "Lelaki Seks Lelaki” di Kota Padang Sumatera Barat. (2018) 7:3 Jurnal Kesehatan Andalas.

Heather Fay. Stigma, Health Care Access, and HIV Knowledge Among Men Who Have Sex With Men in Malawi, Namibia, and Botswana. (2011) 15:6 AIDS Behav.

Ignatius Praptorahardjo, et al. Kebijakan HIV \& AIDS dalam Sistem Kesehatan di Indonesia : Ringkasan Kajian Dokumen. (Yogyakarta : Pusat Kebijakan dan Manajemen Kesehatan Fakultas Kedokteran Universitas Gadjah Mada dan Departement of Foreign affairs and Trade, Austalian Government, 2014).

Irma Rosalinda Lubis \& Ananda Rasullia. Penerimaan Diri pada Istri yang Memiliki Suami Homoseksual. (2014) 3:2 Jurnal Penelitian dan Pengukuran Psikologi.

Jember District Health Office. Jember District Health Profile: Jember. (Jember: Jember District Health Department, 2016).

Jember District Health Office. Laporan Program Penanggulangan HIV dan AIDS di Kabupaten Jember Tahun 2016. (Jember: Bidang P2PL Dinas Kesehatan Kabupaten Jember, 2016).

Jennifer A. Pellowsky, et al. A Pandemic of the Poor: Social Disadvantage and the U.S. HIV Epidemic. (2014) 68:4 National Institute of Health.

Jokie M.S. Siahaan. Perilaku Menyimpang: Pendekatan Sosiologi. (Jakarta: PT. Indeks, 2009). 
Kathryn Risher, et al. Sexual Stigma and Discrimination as Barriers to Seeking Appropriate Healthcare Among Men Who Have Sex With Men in Swaziland. (2013) 16:3 Suppl 2 Journal of the International AIDS Society.

Kevin John Zimmerman. Maintaining Commitment in Long-Lasting Mixedorientation Relationships: Gay Men Married to Straight Women. (2013) Lowa State University Digital Repository.

LaRon E. Nelson, et al. Economic, Legal, and Social Hardship Associated with HIV Risk among Black Men Who Have Sex With Men in Six US Cities. (2016) 93:1 Journal of Urban Health: Bulletin of the New York Academy of Medicine.

Maria A. Pando, et al. HIV Knowledge and Beliefs among Men Who Have Sex With Men (MSM) in Buenos Aires, Argentina. (2013) 17:4 AIDS Behav.

Maria M. Pontoh, et al. Hubungan Pola Asuh Orang Tua dengan Tingkat Homoseksual Pada Komunitas GayX di Manado. (2015) 3:3 Jurnal e-Biomedik (eBm).

Murugi Micheni, et al. Health Provider Views on Improving Antiretroviral Therapy Adherence Among Men Who Have Sex with Men in Coastal Kenya. (2017) 31:7 AIDS PATIENTS CARE and STDs.

National AIDS Commission. National AIDS Commission 2007-2010 HIV and AIDS Response Strategies. National AIDS Commission, 2007).

Olivia J.S. Taebenu. The Protection of LGBT (Lesbian, Gay, Bisexual, Transgender) Rights According to Human Rights. (2014) 2:8 Lex Ex Societatis.

Sarlito W. Sarwono. Psikologi Lintas Budaya. (Jakarta: PT Raja Grafindo Persada, 2014).

Stacey A. Rizza, et al. HIV Screening in The Health Care Setting: Status, Barriers, and Potential Solution. (2012) 87:9 Symposium On Antimicrobial Therapy.

Suherry, et al. Lesbian, Gay Biseksual dan Transgender (LGBT) Dalam Perpektif Masyarakat dan Agama. (2016) 4:2 Jurnal Aristo.

The Law of the Republic of Indonesia Number 16 Year 2019 concerning Amendment to Law Number 1 of 1974 concerning Marriage.

The Ministry of Health of the Republic of Indonesia. STBP (Surveilens Terpadu Biologis dan Perilaku). (Jakarta: Direktorat Jenderal Pengendalian Penyakit dan Penyehatan Lingkungan, 2013).

Toby Miles-Johnson \& Yurong Wang. "Hidden Identities": Perception of Sexual Identity in Beijing. (2018) 69:2 The British Journal of Sociology.

Yu Liu, et al. Barriers and Facilitators of Linkage to and Engagement in HIV Care Among HIV-Positive Men Who Have Sex with Men in China: A Qualitative Study. (2016) 30:2 Journal of AIDS Patient Care and Sexual Transmitted Disease.

Yuji Feng, et al. (2011). Evolution of MSM Community and Experienced in Stigma Among MSM in Chengdu, China. (2011) NIH Public Access.

Yulianti Muthmainnah. LGBT Human Rights in Indonesia Policies. (2016) 4:1 Indonesian Feminist Journal. 
152 | Outlining Gay's Right to Health in Jember, Indonesia: Challenges and Opportunities

This page intentionally left blank 